\title{
UPAYA MENINGKATKAN KETERAMPILAN BERKOMUNIKASI MELALUI PERCAKAPAN TELEPON SISWA SEKOLAH DASAR KELAS 3 DENGAN PENERAPAN MODEL PEMBELAJARAN KOOPERATIF TIPE INSIDE-OUTSIDE CIRCLE
}

\author{
Candra Dewi \\ IKIP PGRI Madiun \\ candra_cincun@yahoo.com
}

\begin{abstract}
This study aims to improve communication skills through telephone conversations Elementary School third grade through the implementation of cooperative learning model inside-outside circle. Lessons Indonesian considered a boring lesson. Student learning just listening to the teacher and then work on the problems that the learning outcomes especially in the Indonesian speaking skills still low. The learning problems require solutions that learning can run well and get a satisfactory learning outcomes. One solution that can be implemented that type of cooperative learning model insideoutside circle. This research is a class act (Clasroom action research). Procedure-class research carried out through several stages depicted in two cycles and each cycle consisting of several steps that must be carried out activities such as: (1) planning; (2) implementation of the action; (3) observations; and (4) reflection. Data collection techniques is done through observation, interviews and tests. The study concluded that after research carried out by two cycles, an increase in communication skills through telephone conversations. This is evidenced from the increased percentage of mastery of learning outcomes and the average grade in each cycle. An increasing communication skills due to applied learning models kooepratif type of inside-outside circle on learning Indonesian telephone conversation material.
\end{abstract}

Keywords: Communication Skills, Cooperative Learning Model, Type Inside Outside Circle

\begin{abstract}
ABSTRAK
Penelitian ini bertujuan untuk meningkatkan keterampilan berkomunikasi melalui percakapan telepon Sekolah Dasar kelas 3 melalui penerapan model pembelajaran kooperatif tipe inside-outside circle. Pelajaran Bahasa Indonesia dianggap sebagai pelajaran yang membosankan. Dalam pembelajaran siswa hanya mendengarkan penjelasan guru kemudian mengerjakan soal sehingga hasil belajar Bahasa Indonesia khusunya pada keterampilan berbicara tergolong masih rendah. Permasalahan pembelajaran tersebut memerlukan solusi supaya pembelajaran dapat berjalan dengan baik dan mendapatkan hasil belajar yang memuaskan. Salah satu solusi yang dapat diterapkan yaitu pembelajaran menggunakan model kooperatif tipe inside-outside circle. Penelitian ini merupakan penelitian tindakan kelas (Clasroom action research). Prosedur penelitian kelas dilaksanakan melalui beberapa tahapan yang digambarkan dalam dua siklus dan tiap siklus terdiri dari beberapa langkah kegiatan yang harus
\end{abstract}


dilakukan antara lain: (1) perencanaan; (2) pelaksanaan tindakan; (3) pengamatan; dan (4) refleksi. Teknik pengumpulan data yang dilakukan yaitu melalui observasi, wawancara dan tes. Penelitian ini menyimpulkan bahwa setelah dilaksanakan penelitian dengan 2 siklus, terjadi peningkatan keterampilan berkomunikasi melalui percakapan telepon. Hal ini dibuktikan dari adanya peningkatan prosentase ketuntasan hasil belajar dan rata-rata kelas pada setiap siklusnya. Terjadinya peningkatan keterampilan berkomunikasi dikarenakan diterapkan model pembelajaran kooepratif tipe insideoutside circle pada pembelajaran Bahasa Indonesia materi percakapan telepon.

Kata Kunci : Keterampilan Berkomunikasi, Model Pembelajaran Kooperatif, Tipe Inside-Outside Circle

\section{PENDAHULUAN}

Pendidikan merupakan salah satu hal yang tidak bisa dipisahkan dalam kehidupan manusia karena sifatnya yang begitu penting sebagai bekal dimasa depan. Indonesia merupakan negara yang menjungjung tinggi pendidikan. Setiap penyelanggaraan pendidikan harus disesuaikan dengan tujuan pendidikan. Pendidikan yang baik dapat menghasilkan masyarakat yang baik pula.

Menurut Isah Cahyani (2009: 36)

Bahasan Indonesia adalah alat komunikasi yang dipergunakan oleh masyarakat Indonesia untuk keperluan sehari-hari, misalnya belajar, bekerja sama dan berinteraksi. Belajar bahasa merupakan usaha yang panjang dan kompleks seluruh jiwa raga yang terlibat ketika memplejari bahasa.

Belajar Bahasa Indonesia berarti juga belajar berkomunikasi karena terdapat interaksi baik antara siswa dengan siswa maupun siswa dengan guru. Agar interaksi dapat bermakna bagi siswa perlu didesain secara tepat rencana pembelajaran bahasa Indonesia. Keterampilan berbicara siswa sangat erat kaitannya dengan keterampilan berkomunikasi. Kata komunikasi berasal dari bahasa latin ,communis ${ }^{c e}$ yang berarti "bersama"e (Inge Hutagalung, 2007: 65). Pendapat lain oleh Sardiman (2011: 7-8) mengartikan bahwa istilah komunikasi yang berasal dari kata "communicare" yang berarti "berpartisipasi", "memberitahukan", "menjadi milik bersama". 
Pembelajaran merupakan hal yang rumit karena dalam kegiatan belajar mengajar tidak hanya sekedar memberi dan menyerap informasi namun juga harus melibatkan berbagai komponen dan kegiatan demi tercapainya tujuan pembelajaran dan hasil belajar yang baik termasuk diantaranya keterampilan berkomunikasi melalui percakapan telepon. Dibeberapa tempat yang menyelenggarakan pendidikan masih menemui kendala dalam pembelajaran Bahasa Indonesia keterampilan berkomunikasi melalui percakapan telepon. Salah satu kendalanya adalah lemahnya proses pembelajaran dikarenakan siswa belum sepenuhnya didorong untuk berfikir secara kritis dan berkomunikasi dengan sesamanya. Pembelajaran di kelas masih didominasi oleh guru dan siswa masih cenderung pasif. Siswa yang pasif dalam pembelajaran dikhawatirkan akan mendapatkan hasil belajar yang kurang baik.

Permasalahan pembelajaran tersebut memerlukan solusi supaya pembelajaran dapat berjalan dengan baik dan mendapatkan hasil belajar yang memuaskan. Salah satu solusi yang dapat diterapkan yaitu pembelajaran menggunakan model kooperatif. Pembelajaran kooperatif adalah pendekatan pembelajaran yang berfokus pada penggunaan kelompok kecil siswa untuk bekerja sama dalam memaksimalkan kondisi belajar untuk mencapai tujuan belajar. Pembelajaran kooperatif merujuk pada berbagai macam metode pengajaran dimana para siswa bekerja dalam kelompokkelompok kecil untuk saling membantu satu sama lainnya dalam mempelajari materi pelajaran (Slavin, 2005: 4). Salah satu tipe pembelajaran kooperatif yang cocok digunakan dalam pembelajaran Bahasa Indonesia untuk meningkatkan ketrampilan berkomunikasi adalah tipe inside-outside circle. Menurut (Anita Lie, 2008:65), IOC merupakan pembelajaran yang memberikan kesempatan pada siswa agar saling berbagi informasi pada saat yang bersamaan. Dalam pembelajaran IOC ketika siswa saling 
berbagi muncul sikap kerjasama dan saling membantu antara siswa satu dengan lainnya.

Sedangkan menurut Menurut Slameto (2010

: 28) Inside Outside Circle(IOC) ini merupakan salah satu tipe dari Cooperative Learning yang bertujuan untuk melatih peserta didik belajar mandiri dan belajar berbicara, menyampaikan informasi kepada orang lain. Selain itu juga melatih kedisiplinan dan ketertiban peserta didik, serta menumbuhkan kemampuan berfikir mandiri.

Menurut Anita Lie (2008 : 68) langkah-langkah pembelajaran IOC Antara lain: (1) separuh kelas berdiri membentuk lingkaran kecil dan menghadap keluar; (2) separuh kelas lainnya membentuk lingkaran di luar lingkaran pertama, menghadap kedalam; (3) dua peserta didik yang berpasangan dari lingkaran kecil dan besar saling mengungkapkan pemahaman mereka tentang materi yang baru saja diterima. Pertukaran informasi ini bisa dilakukan oleh semua pasangan dalam waktu yang bersamaan; (4) kemudian peserta didik berada di lingkaran kecil diam di tempat, sementara peserta didik yang berada di lingkaran besar bergeser satu atau dua langkah searah jarum jam sehingga masingmasing peserta didik mendapat pasangan baru;(5) sekarang giliran peserta didik berada di lingkaran besar yang membagi informasi.

Demikian seterusnya.

Dalam pelaksanaan pembelajaran kooperatif tipe inside-outside circle (IOC) diharapkan siswa akan bisa saling berkomunikasi, membantu, berbagi dan bekerja sama antara satu dengan yang lainnya. Pembelajaran dengan menggunakan model pembelajaran kooperatif tipe insideoutside circle (IOC) sesuai dengan tingkat perkembangan anak usia Sekolah Dasar terutama kelas rendah. Piaget mengemukakan bahwa siswa SD berada pada tahap operasional konkret (7 hingga 11 tahun), dimana konsep yang ada pada awal usia ini adalah konsep yang samar-samar dan sekarang lebih konkret. Siswa usia SD 
menggunakan operasi mental untuk memecahkan masalah-masalah aktual, siswa mampu menggunakan kemampuan mentalnya untuk memecahkan masalah yang bersifat konkret (Rita Eka Izzaty, dkk., 2008: 105). Dari pembelajaran IOC siswa dituntut untuk berpikir logis dan berkomunikasi dengan temannya karena tingkat berpikirnya sudah tidak lagi egosentris dan sudah mampu berpikir secara logis.

\section{METODOLOGI PENELITIAN}

Penelitian ini dilaksanakan pada siswa kelas 3 Sekolah Dasar dan dilaksankan pada bulan Januari-Mei 2016. Metode penelitian yang digunakan yaitu metode penelitian tindakan kelas (Clasroom action research). PTK adalah suatu penelitian praktis yang bertujuan untuk memperbaiki kekurangan-kekurangan dalam pembelajaran di kelas, dengan cara melakukan tindakantindakan tertentu agar dapat memperbaiki dan atau meningkatkan praktik-praktik pembelajaran di kelas secara lebih professional. Pendapat lain mengenai PTK dikemukakan oleh Kunandar (2008: 46) yaitu penelitian tindakan kelas adalah sebuah bentuk kegiatan refleksi diri yang dilakukan oleh para pelaku pendidikan dalam suatu situasi pendidikan untuk memperbaiki rasionalitas dankeadilan tentang: (a) praktikpraktik kependidikan mereka, pemahaman mereka tentang praktik-praktik tersebut, dan (c) situasi dimana praktikpraktik tersebut dilaksanakan.

Tujuan dari penelitian ini yaitu memperbaiki dan meningkatkan keterampilan berkomunikasi melalui percakapan telepon secara berkesinambungan dan diharapkan dapat memperbaiki kekurangan-kekurangan yang ada dalam proses pembelajaran Bahasa Indonesia yang dilakukakan sebelumnya. Prosedur penelitian kelas dilaksanakan melalui beberapa tahapan yang digambarkan dalam dua siklus dan tiap-tiap siklusnya terdapat beberapa langkah kegiatan yang harus dilakukan antara lain: (1) perencanaan; 
(2) pelaksanaan tindakan; (3) pengamatan;

dan (4) refleksi. Dalam pengumpulan data peneliti menggunakan tiga teknik pengumpulan yaitu melalui observasi, wawancara dan tes. Peneliti mengobservasi kegiatan pembelajaran sebelum maupun selama dilakukan pembelajaran tiap siklusnya dan melakukan wawancara terhadap guru dan siswa mengenai pembelajaran yang sudah dilakukakan.

Setelah itu melakukan tes yang dilaksanakan pada akhir siklus. Teknik analisis data yang digunakan dalam penelitian ini adalah teknik analisis interaktif. Teknik analisis interaktif ini mempunyai tiga komponen pokok yaitu: (1) reduksi data, (2) penyajian data, (3) penarikan simpulan atau verifikasi. Indikator keberhasilan dalam penelitian ini adalah $85 \%$ siswa mendapat nilai Bahasa Indonesia keterampilan berkomunikasi melalui percakapan telepon dengan skor $\geq 80$ dan diukur dengan lembar observasi dan tes, serta nilai rata-rata kelas $\geq 80$
HASIL PENELITIAN DAN PEMBAHASAN

Pra Siklus

Penelitian ini diawali dengan observasi terhadap proses pembelajaran dan wawancara kepada guru dan siswa. Pada tahap observasi di kondisi awal ini diperoleh data bahwa pada kegiatan pembelajaran masih didominasi oleh guru (teacher centered). Guru banyak menggunakan metode ceramah yang sesekali diselingi dengan kalimat pertanyakan kepada siswa. Sedangkan siswa masih cenderung pasif dan kurang memiliki semangat dalam belajar maupun menjawab pertanyaan dari guru. Sebagian siswa masih asik dengan mainannya sendiri dan hanya sebagian kecil siswa yang memperhatikan pennjelasan guru. Setelah dilakukan wawancara dengan siswa ternyata siswa merasa bosan terhadap proses pembelajaran setiap harinya yang monoton karena siswa hanya duduk di bangku mendengarkan penjelasan guru. Hal ini diperkuat oleh pendapat guru bahwa dalam 
proses pembelajaran siswa masih belum termotivasi untuk belajar sehingga hasil belajarnya rendah. Pada pra siklus diperoleh data hasil belajar sebagai berikut.

Tabel 1. Ketuntasan Keterampilan

Berkomunikasi Melalui Percakapan

Telepon

pada Pra Siklus

\begin{tabular}{|c|c|c|c|}
\hline No & Ketuntasan & $\begin{array}{c}\text { Pra } \\
\text { Siklus }\end{array}$ & $\begin{array}{c}\text { Prosentase } \\
\text { ketuntasan }\end{array}$ \\
\hline 1 & Tuntas & 7 & $30 \%$ \\
\hline 2 & $\begin{array}{c}\text { Belum } \\
\text { Tuntas }\end{array}$ & 16 & $70 \%$ \\
\hline & Jumlah & 23 & $100 \%$ \\
\hline \multicolumn{3}{|c|}{$\begin{array}{c}\text { Nilai rata-rata kelas }=63 \\
\text { Prosentase ketuntasan }=30 \%\end{array}$} \\
\hline
\end{tabular}

Berdasarkan pada tabel 1 diperoleh data jumlah siswa yang tuntas sebanyak 7 siswa $(30 \%)$ dan siswa yang tidak tuntas sebanyak 16 siswa (70\%). Sedangkan nilai rata-rata kelasnya yaitu 63. Pembelajaran pada pra siklus menunjukkan bahwa kegiatan pembelajaran masih belum berhasil mencapai tujuan pembelajaran karena masih banyak siswa yang belum tuntas hasil belajarnya.
Kekurangan dalam pembelajaran pada pra siklus diperbaiki pada siklus 1 yaitu dengan menerapkan model pembelajaran kooperatif tipe inside-outside circle. Dalam penerapan model tersebut siswa sudah mulai aktif dalam kegiatan pembelajaran. Siswa dilatih untuk berdiskusi, berkerjasama, berbagi dan saling membantu dalam pembelajaran. Sehingga dari kemajuan ini diharapkan dapat meningkatkan keterampilan berkomunikasi melalui percakapan telepon. Namun pada siklus 1 masih ditemuai kekurangan yaitu ketika guru menerapkan menerapakan inside-outside circle siswa masih berusaha keras menyesuaikan diri dengan gaya belajar yang baru. Masih banyak pula siswa yang merasa kebingunangan dalam menerapkan sehingga suasana kelas masih gaduh. Pada siklus 1 diperoleh data hasil belajar sebagai berikut.

Siklus 1 
Tabel 2. Ketuntasan Keterampilan

Berkomunikasi Melalui Percakapan

Telepon pada Siklus 1

\begin{tabular}{|c|c|c|c|}
\hline No & Ketuntasan & Siklus 1 & Prosentase \\
\hline 1 & Tuntas & 14 & $60 \%$ \\
\hline 2 & $\begin{array}{c}\text { Belum } \\
\text { Tuntas }\end{array}$ & 9 & $40 \%$ \\
\hline & Jumlah & 23 & $100 \%$ \\
\hline \multicolumn{3}{|c|}{$\begin{array}{c}\text { Nilai rata-rata kelas }=73 \\
\text { Prosentase ketuntasan }=60 \%\end{array}$} \\
\hline
\end{tabular}

Berdasarkan pada tabel 2 diperoleh data siswa yang tuntas hasil belajar sebanyak 14 siswa (60\%), dan siswa yang tidak tuntas hasil belajar sebanyak 9 siswa (40\%). Prosentase ketuntasan mengalami peningkatan dari pra siklus sebesar $30 \%$ meningkat menjadi $60 \%$ pada siklus 1 , namun ini masih belum memenuhi indikator kinerja yang sudah ditetapkan. Untuk nilai rata-rata kelas juga mengalami peningkatan dari pra siklus sebesar 63 menjadi 73 . Prosentase ketuntasan dan hasil belajar pada siklus 1 belum memenuhi indikator kinerja yang sudah ditetapkan maka dari itu pembelajaran diteruskan pada siklus 2 .
Siklus 2

Setelah diadakan refleksi pada siklus 1 dan ditemukan kekurangannya, maka diadakan perbaikan pada siklus 2. Perbaikan ini lebih ditekankan pada pengelolaan kelas dan penjelasan aturan bermain. Guru lebih aktif dan antusian untuk dapat mengelola kelas dengan baik sehingga tidak ada siswa yang merasa kebingungan dan kesulitan untuk mengikuti pembelajaran. Sikap terbuka sangat diperlukan oleh guru untuk menampung segala pertanyaan yang diutaran oleh siswa yang masih kurang mengerti. Guru juga aktif membimbing diskusi tia-tiap siswa. Pada siklus 2 siswa sudah mengerti dan dapat mengikuti pembelajaran yang dilakukan sehingga banyak yang merasa sudah paham terhadap materi pembelajaran. Pada siklus 2 diperoleh data hasil belajar sebagai berikut: 
Tabel 3. Ketuntasan Keterampilan

Berkomunikasi Melalui Percakapan

Telepon pada Siklus 1

\begin{tabular}{|c|c|c|c|}
\hline No & Ketuntasan & Siklus 2 & Prosentase \\
\hline 1 & Tuntas & 20 & $87 \%$ \\
\hline 2 & $\begin{array}{l}\text { Belum } \\
\text { Tuntas }\end{array}$ & 3 & $13 \%$ \\
\hline & Jumlah & 23 & $100 \%$ \\
\hline \multicolumn{3}{|c|}{$\begin{array}{c}\text { Nilai rata-rata kelas }=85 \\
\text { Prosentase ketuntasan }=87 \%\end{array}$} \\
\hline
\end{tabular}

Berdasarkan pada tabel 3 diperoleh data siswa yang tuntas ketrampilan berkomunikasi sebanyak 20 siswa (87\%), sedangkan siswa yang tidak tuntas ketrampilan berkomunikasi sebesar 3 siswa (13\%). Prosentase ketuntasan mengalami peningkatan dari siklus 1 sebesar $60 \%$ menjadi $87 \%$ pada siklus 2 . Rata-rata kelas juga mengalami peningkatan dari siklus 1 sebesar 73 menjadi 85 pada siklus 2 . Prosentase dan nilai rata-rata kelas sudah memenuhi indikator kinerja maka peneliti menghentikan pembelajaran dan tidak melanjutkan lagi pada siklus berikutnya.

Berdasarkan data yang diperoleh pada tabel 1, 2 dan 3 maka dapat dilihat perbandingan prosentase ketuntasan dan rata- rata kelas pada pra siklus, siklus 1 dan siklus 2 pada tabel dibawah ini.

Tabel 4. Perbandingan Prosentase Ketuntasan Pada Pra Siklus, Siklus 1 Dan Siklus 2

\begin{tabular}{|c|c|c|}
\hline No & Ketuntasan & $\begin{array}{c}\text { Prosentase } \\
\text { ketuntasan }\end{array}$ \\
\hline 1 & Pra Siklus & $30 \%$ \\
\hline 2 & Siklus 1 & $60 \%$ \\
\hline 3 & Siklus 2 & $87 \%$ \\
\hline
\end{tabular}

Terdapat kenaikan baik dalam prosentase ketuntasan dan rata-rata kelas pada setiap siklusnya. Prosentase ketuntasan pada pra siklus sebesar $30 \%$ mengalami kenaikan sebesar $30 \%$ menjadi $60 \%$ pada siklus 1. Kemudian prosentase ketuntasan pada siklus 1 sebesar $60 \%$ mengalami kenaikan sebesar $27 \%$ menjadi $87 \%$ pada siklus 2. Perbandingan peningkatan prosentase ketuntasan pada pra siklus, siklus 1 dan siklus 2 dapat dilihat pada gambar 1 . 
Gambar 1. Perbandingan prosentase ketuntasan pada pra siklus, siklus 1 dan siklus 2

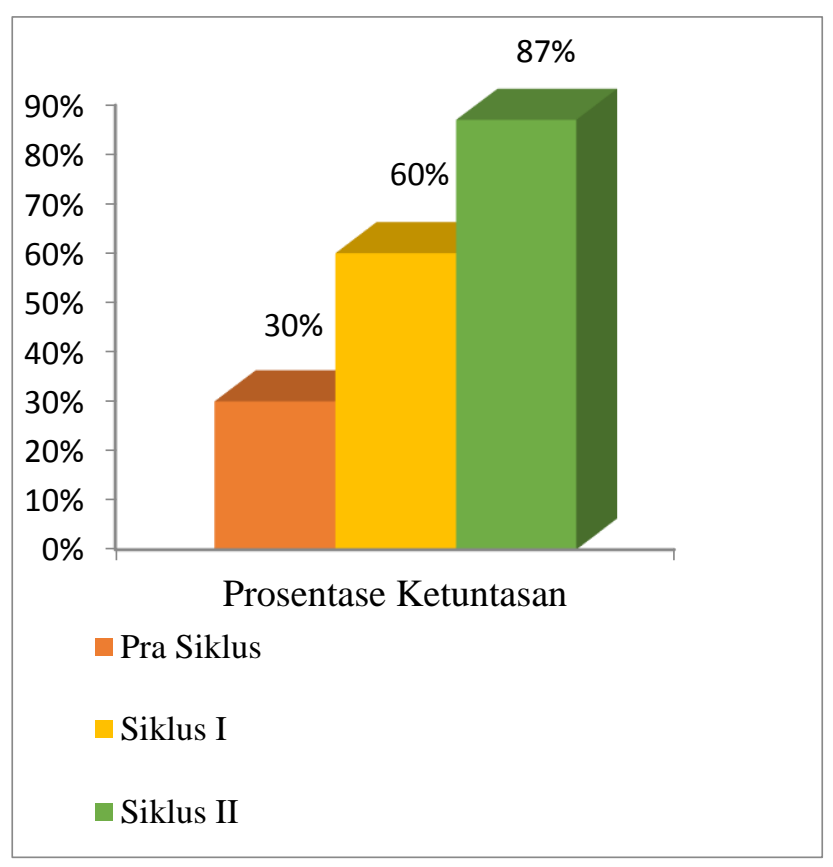

Nilai rata-rata kelas juga mengalami kenaikan dari pra siklus menuju siklus 1 dan siklus 2. Pada pra siklus rata-rata kelas sebesar 63 mengalami kenaikan sebesar 10 menjadi 73 pada siklus 1 . Kemudia rata-rata kelas juga mengalami keniakan lagi pada siklus 2 menjadi $85 . \quad$ Perbandingan peningkatan hasil belajar pada pra siklus, siklus 1 dan siklus 2 dapat dilihat pada tabel 5 dan gambar 2.
Tabel 5. Perbandingan Rata-Rata Kelas Pada Pra Siklus, Siklus 1 Dan Siklus 2

\begin{tabular}{|c|c|c|}
\hline No & Ketuntasan & Rata-rata \\
\hline 1 & Pra Siklus & 63 \\
\hline 2 & Siklus 1 & 73 \\
\hline 3 & Siklus 2 & 85 \\
\hline
\end{tabular}

Gambar 2. Perbandingan Nilai Rata-Rata Pada Pra Siklus, Siklus 1 Dan Siklus 2

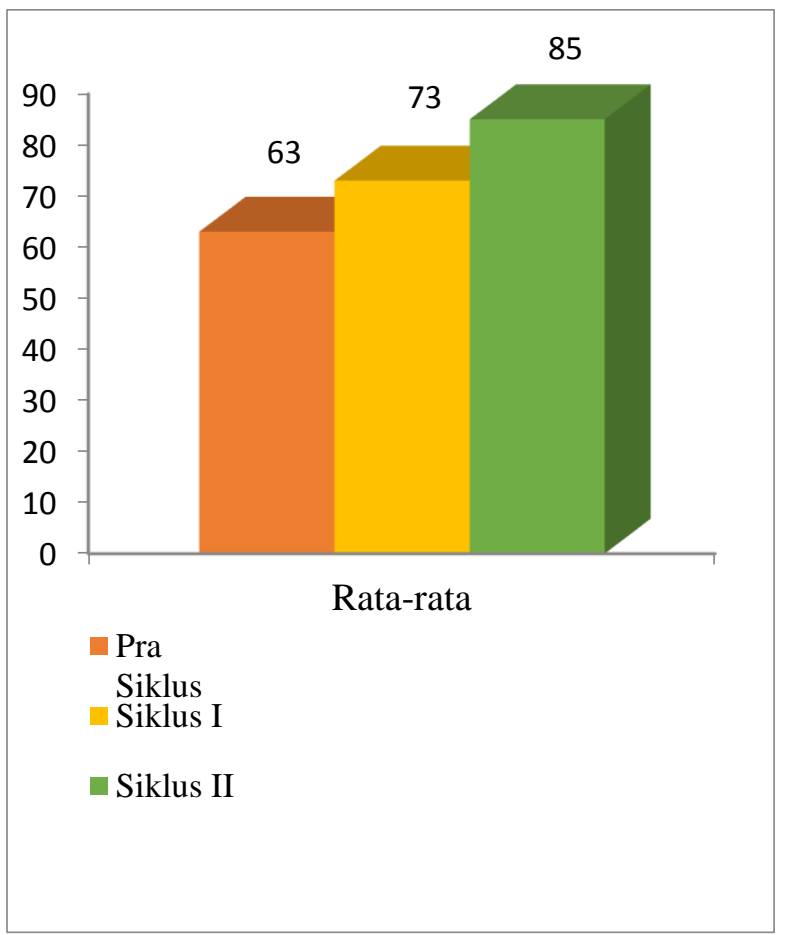

Berdasarkan gambar 1 dan gambar 2 diatas, dapat diketahui bahwa penerapan model pembelajaran kooperatif insideoutside circle pada pembelajaran Bahasa Indonesia keterampilan berkomunikasi melalui percakapan telepon kelas 3 Sekolah Dasar dapat meningkatkan keterampilan berkomunikasi melalui percakapan telepon. 
Maka dapat dikatakan dengan menerapakan model pembelajaran kooperatif tipe insideoutside circle dapat meningkatkan keterampilan berkomunikasi melalui percakapan telepon siswa kelas 3 Sekolah Dasar.

\section{SIMPULAN DAN SARAN}

Berdasarkan Penelitian Tindakan Kelas (PTK) yang dilakukan pada kelas 3 Sekolah Dasar dapat ditarik kesimpulan yaitu pelaksanaan pembelajaran Bahasa Indonesia keterampilan berkomunikasi melalui percakapan telepon dengan menerapkan model pembelajaran kooperatif tipe insideoutside circle dapat meningkatkan keterampilan berkomunikasi melalui percakapan telepon Setelah dilaksanakan penelitian dengan 2 siklus dimana tiap siklus didapatkan hasil bahwa dari tindakan satu sampai tindakan terakhir ada peningkatan hasil belajar. Hal ini dibuktikan dari adanya peningkatan prosentase ketuntasan hasil belajar dan rata-rata kelas. Terjadinya peningkatan hasil belajar dikarenakan diterapkan model pembelajaran kooepratif tipe inside-outside circle pada pembelajaran Bahasa Indonesia keterampilan berkomunikasi melalui percakapan telepon.

Berdasarkan hasil penelitian tindakan kelas melalui penerapan model pembelajaran kooepratif tipe inside-outside circle untuk meningkatkan ketrampilan berkomunikasi melalui percakapan telepon kelas 3 Sekolah Dasar peneliti meberikan saran khususnya kepada guru-guru Sekolah Dasar untuk memberikan inovasi pembelajaran kepada siswa-siswanya sesuai dengan tingkat perkembangan siswa. Guru hendaknya mengetahui karakteristik masing-masing siswanya sehingga guru dapat mengetahui gaya belajar yang diperlukan siswanya. Inovasi pembelajaran sangat penting dilakukan untuk mengatasi rasa bosan pada siswa ketika belajar di kelas. 


\section{DAFTAR PUSTAKA}

A.M. Sardiman. 2011. Interaksi dan Motivasi Belajar Mengajar. Jakarta: Rajagrafindo.

Anita Lie. 2008. Cooperative Learning: Mempraktikkan Cooperative Learning Di Ruang-ruang Kelas, Jakarta: Grasindo.

Inge Hutagalung. 2007. Pengembangan Kepribadian. Jakarta: Indeks

Isah Cahyani. 2009. Pendidikan Bahasa Indonesia. Bandung : Upi Pres

Kunandar. 2008. Langkah Mudah Penelitian Tindakan Kelas Sebagai Pengembangan Profesi Guru. Jakarta: Rajawali Pers.

Rita Eka Izzaty, Dkk. 2008. Perkembangan Peserta Didik. Yogyakarta: UNY Press.

Slameto. 2010. Belajar dan Faktor-Faktor yang Mempengaruhinya. Jakarta: Rineka Cipta.

Slavin, Robert E. 2005. Cooperative Learning: theory, research and practice (N. Yusron. Terjemahan). London: Allymand Bacon. Buku asli diterbitkan tahun 2005.

Sugihartono, dkk. 2007. Psikologi Pendidikan. Yogyakarta: UNY Press. 